\title{
A NOVEL ROUTE FOR SYNTHESIS OF SENDAVERINE
}

\author{
ANITA A. PANDEY ${ }^{1}$
}

Department of Chemistry, D.S. (P.G.) College, Aligarh, U.P., India

\begin{abstract}
The present work describes a novel synthetic route for Sendaverine, a N-benzyl-1,2,3,4-teteahydroisoquinoline alkaloid, using chloromethyl-methyl ether for cyclisation of $\mathrm{N}$-anisoyl derivative of substituted $\beta$-phenethyl amine followed by reduction with $\mathrm{LiAlH}_{4}$ and debenzylation.
\end{abstract}

KEYWORDS: N-benzyl-1,2,3,4-tetrahydroisoquinoline, Chloromethyl-methyl ether, Cyclisation, Reduction, Debenzylation

Sendaverine (8) is an optically inactive phenolic alkaloid which was isolated from Corydalis aurea Wild. (Fam. Fumariaceae) by Manske (Manske, 1952). The structural formula (8) of Sendaverine was assigned to the alkaloid by Manske on the basis of degradative and spectral evidences (Manske, 1952) (Kametani and Okhubo, 1967) (Kametani et al., 1966) (Otoman, 1982) (Budzikiewics et al., 1964) (Kametani and Okhubo, 1965) (Kametani et al., 1967). In the present work a novel synthesis of Sendaverine has been achieved by using chloromethyl-methyl ether for cyclisation of $\mathrm{N}$ anisoyl derivative of substituted $\beta$-phenethyl amine followed by reduction with $\mathrm{LiAlH}_{4}$ and debenzylation.

Vanillin (1) on benzylation with benzyl chloride gave the O-benzyl vanillin (2) which on treatment with nitromethane gave 4-benzyloxy-3-methoxy- $\omega$-nitro styrene (3). This on reduction with Lithium aluminium hydride gave 2-(4'-benzyloxy-3'-methoxy phenyl) ethyl amine (4). This was treated with anisoyl chloride to give the $\mathrm{N}$-anisoyl derivative of the amine(5) which was treated with monochloromethyl ether to give N-anisoyl-7benzyloxy-6-methoxy-1,2,3,4-tetrahydroisoquinoline (6) and this on reduction with $\mathrm{LiAlH}_{4}$ followed by debenzylation with ethanol - hydrochloric acid mixture gave Sendaverine (8) as shown in the scheme as follows.

\section{EXPERIMENTAL}

(I) Synthesis of O-benzyl vanillin: (2) A mixture of vanillin (1)(7.6 g), anh. potassium carbonate $(5.0 \mathrm{~g})$, benzyl chloride $(4 \mathrm{~mL})$, sodium iodide $(0.4 \mathrm{~g})$ and ethanol $(130 \mathrm{~mL})$ was stirred and refluxed for $6 \mathrm{~h}$. After cooling, the solvent was distilled out in vacuo and resulting oil poured into alkaline ice cold water $(250 \mathrm{~mL})$. The solid product was crushed under water, filtered and dried $\left(\mathrm{Na}_{2} \mathrm{SO}_{4}\right)$. Recrystallisation from aq. ethanol gave Obenzyl vanillin (2). (9.6 g; 79.34\%), m.p. $64-65^{\circ} \mathrm{C}$.

(Found C,74.2, H,5.96, O-19.8, $\mathrm{C}_{15} \mathrm{H}_{14} \mathrm{O}_{3}$ requires $\mathrm{C} 74.5$; H 5.78; O 19.9\%)

(II) Synthesis of 4-benzyloxy-3-methoxy-(1)nitrostyrene:(3)

A mixture of O-benzylvanillin (2) (9g), ammonium acetate $(3 \mathrm{~g})$, nitromethane $(15 \mathrm{~mL})$ and glacial acetic acid $(25 \mathrm{~mL})$ was refluxed for $1.5 \mathrm{~h}$. The crystals of the product which deposited on cooling were filtered, dried and recrystallised from ethanol to give the styrene (3) as yellow needles $(8.47 \mathrm{~g} ; 80 \%)$ m.p. $120-122^{\circ} \mathrm{C}$

(Found C:67.42; $\mathrm{H}: 5.25 ; \mathrm{N}: 4.90 ; \mathrm{C}_{16} \mathrm{H}_{15} \mathrm{NO}_{4}$ requires C:67.36; H:5.26; N:4.91\%)

\section{(III) Synthesis of 4-benzyloxy-3-methoxy- $\beta$ -} phenethylamine: (4)

To a stirred suspension of lithium aluminium hydride $(5.36 \mathrm{~g})$ in tetrahydrofuran was added the styrene (3) $(8 g)$, in portions, with ice bath cooling. The mixture was refluxed at $100^{\circ} \mathrm{C}$ for $4 \mathrm{~h}$, cooled, excess hydride was decomposed by addition of water and mixture was extracted with methylene dichloride. The extract was washed with $2 \mathrm{~N}$ aq. sodium hydroxide, washed with water, dried $\left(\mathrm{Na}_{2} \mathrm{SO}_{4}\right)$ and solvent removed to give the amine as oil $(5.62 \mathrm{~g}, 78 \%)$. The hydrochloride had m.p. $171-172^{0} \mathrm{C}$. 
<smiles>COc1cc(C=O)ccc1O</smiles>

(1)<smiles>COc1cc(C=O)ccc1OC(=O)O</smiles>

(2)<smiles>COc1cc(/C=C\[N+](=O)[O-])ccc1OC(=O)c1ccccc1</smiles>

(3)

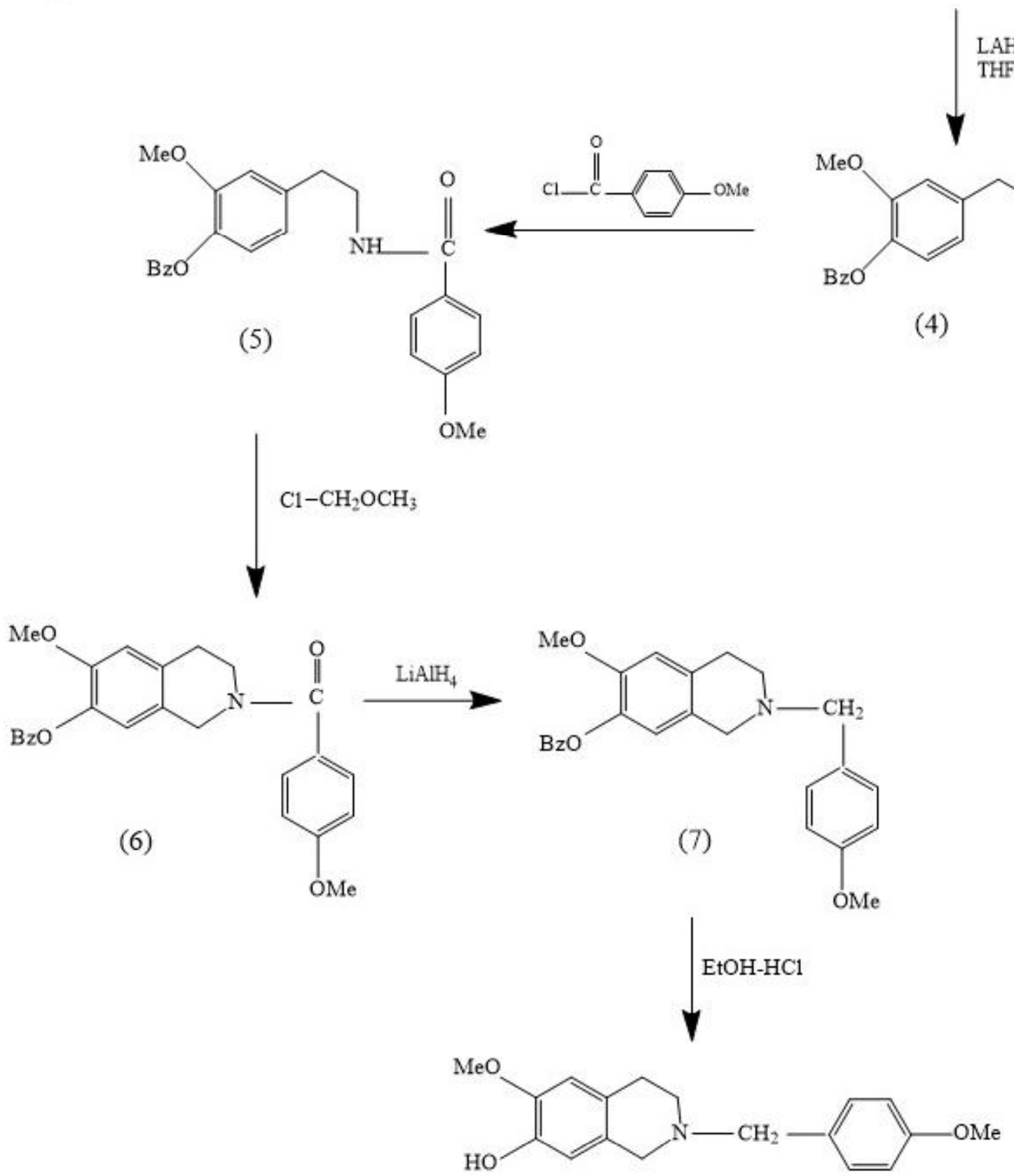

(8)

SENDAVERINE 
(IV)Synthesis of N-anisoyl-2-(4'-benzyloxy-3'-methoxy phenyl) ethyl amine (5)

To a stirred mixture of 2-(4'-benzyloxy-3'methoxy phenyl) ethyl amine (5) $(4 \mathrm{~g})$ in benzene $(22 \mathrm{~mL})$ and $10 \% \mathrm{NaOH}(80 \mathrm{~mL})$, a solution of anisoyl chloride $(3.75 \mathrm{~g})$ in dry $\mathrm{C}_{6} \mathrm{H}_{6}(150 \mathrm{~mL})$ was slowly added and the stirring was continued for $4 \mathrm{~h}$ at room temperature. The benzene layer was then separated, washed with $1 \mathrm{~N} \mathrm{HCl}$, water, dried $\left(\mathrm{Na}_{2} \mathrm{SO}_{4}\right)$ and the solvent removed under reduced pressure to give (5) $(4.62 \mathrm{~g} ; 77 \%)$; m.p. $190^{\circ} \mathrm{C}$ (ether-hexane)

$\mathrm{IR}(\mathrm{KBr}): \quad 3330 \mathrm{~cm}^{-1} \quad(\mathrm{NH})$ and $1650 \mathrm{~cm}^{-1} \quad(\mathrm{C}=\mathrm{O})$ MS m/e: $391\left(\mathrm{M}^{+}\right)$

(Found C: 73.72; H: 6.38; N:3.44; $\mathrm{C}_{24} \mathrm{H}_{25} \mathrm{NO}_{4}$ requires C: $73.661 \mathrm{H}: 6.4 ; \mathrm{N}: 3.58 \%)$

(V) Synthesis of N-Anisoyl-7-benzyloxy-6-methoxy1,2,3,4-tetrahydroisoquinoline (6)

A mixture of monochloromethyl ether $(2.5 \mathrm{~g})$ in glacial acetic acid $(30 \mathrm{~mL})$ was treated with N-Anisoyl-2(4'-benzyloxy-3'-methoxy phenyl) ethyl amine (6) (4g) at about $18^{\circ} \mathrm{C}$ for twenty-four hour. The excess solvent and reagent were removed under reduced pressure. The residue was washed with $20 \% \mathrm{NH}_{3}$ solution, extracted with ethyl acetate, washed with water, dried $\left(\mathrm{Na}_{2} \mathrm{SO}_{4}\right)$ and the solvent removed to obtain (6) $(2.96 \mathrm{~g} ; 72 \%)$ m.p. $158^{0} \mathrm{C}$.

$\mathrm{IR}(\mathrm{KBr}): 1660 \mathrm{~cm}^{-1}(\mathrm{C}=\mathrm{O})$

(Found C: 74.18; H: 6.24; N: 3.54; $\mathrm{C}_{24} \mathrm{H}_{25} \mathrm{NO}_{4}$ requires C: $74.44 ; \mathrm{H}: 6.2$; N: $3.47 \%)$

(VI)Synthesis of 7-benzyloxy-6-methoxy-2-(4'methoxy benzyl)-1,2,3,4-tetrahydroisoquinoline (7)

The product (6) (2.5g) obtained in previous step was added in portions to a well stirred suspension of Lithium aluminium hydride (7.2g) in anh. Tetrahydrofuran $(100 \mathrm{~mL})$ over a period of $45 \mathrm{~min}$. The mixture was stirred and refluxed for $8 \mathrm{~h}$. on a water bath. The mixture was cooled and excess hydride was decomposed with moist ethyl acetate and the solution was rendered alkaline with aq. Sodium hydroxide solution. The organic layer which separated was extracted with dilute hydrochloric acid and extracts were made alkaline to give the solid, which was taken in ether and washed with water and dried $\left(\mathrm{Na}_{2} \mathrm{SO}_{4}\right)$. Removal of the solvent gave a solid which was recrystallised from $\mathrm{n}$-hexane to give the substituted tetrahydroisoquinoline (7) as colourless prisms $(1.64 \mathrm{~g}, 68 \%)$ m.p. $91^{\circ} \mathrm{C}$, (Kametani and Okhubo, 1965).

$\mathrm{IR}(\mathrm{KBr}): 2790,2755 \mathrm{~cm}^{-1}$

$\operatorname{NMR}\left(\mathrm{CDCl}_{3}\right): 2.61-2.80\left(4 \mathrm{H}, \mathrm{m},-\mathrm{CH}_{2}-\mathrm{CH}_{2}\right) 3.44,3.56$ (2H each, s, $\left.\mathrm{C}_{1}-\mathrm{H}, \mathrm{N}-\mathrm{CH}_{2}-\mathrm{C}_{6} \mathrm{H}_{4}\right) 3.75,3.80$ (3H each, $\mathrm{S}$, $2 \mathrm{x}-\mathrm{OMe}$ ), $5.00\left(2 \mathrm{H}, \mathrm{s},-\mathrm{OCH}_{2}-\mathrm{Ph}\right) 6.48,6.58$ (1H each, s, $\mathrm{C}_{8} \mathrm{H}$ and $\mathrm{C}_{5} \mathrm{H}$ respectively) $6.82\left(2 \mathrm{H}, \mathrm{d}, \mathrm{J}=8.5 \mathrm{~Hz}, \mathrm{C}_{3},-\mathrm{H}\right.$, $\mathrm{C}_{5},-\mathrm{H}$ respectively) $7.25\left(2 \mathrm{H}, \mathrm{d}, \mathrm{J}=8.5 \mathrm{~Hz} ; \mathrm{C}_{2},-\mathrm{H}, \mathrm{C}_{6} \cdot \mathrm{H}\right)$ ppm.

(Found: C: 77.40; H: 7.16; N: 3.60; $\mathrm{C}_{25} \mathrm{H}_{27} \mathrm{O}_{3} \mathrm{~N}$ requires C: 77.10; H: 6.99; N: 3.61\%)

(VII) Synthesis of 7-hydroxy-6-methoxy-2-(4'methoxybenzyl)-1,2,3,4-tetrahydroisoquinoline; (Sendaverine) (8)

A mixture of O-benzyl derivative (7) (1.1g), ethyl alcohol $(30 \mathrm{~mL})$ and $12 \mathrm{~N} \mathrm{HCl}(30 \mathrm{~mL})$ was heated under reflux for $3 \mathrm{~h}$. The reaction mixture was extracted with ether in order to remove neutral compounds. The acidic layer was basified with 25\% ammonia solution and extracted with benzene. The extract was dried $\left(\mathrm{K}_{2} \mathrm{CO}_{3}\right)$ and removal of the solvent gave a solid whose recrystallisation from n-hexane gave Sendaverine (8) as colourless needles $(0.64 \mathrm{~g} ; \quad 76 \%)$ m.p. $137-138^{\circ} \mathrm{C}$ (Manske, 1952)

$\operatorname{IR}\left(\mathrm{CHCl}_{3}\right): 3546 \mathrm{~cm}^{-1}(-\mathrm{OH}), 2761,2801,2841 \mathrm{~cm}^{-1}$.

NMR $\left(\mathrm{CDCl}_{3}\right) \delta: 2.62-2.86\left(4 \mathrm{H}, \mathrm{m}, \mathrm{C}_{3}-\mathrm{H}\right.$ and $\left.\mathrm{C}_{4}-\mathrm{H}\right) ; 3.45$ $\left(2 \mathrm{H}, \mathrm{s}, \mathrm{N}-\mathrm{CH}_{2}-\mathrm{C}_{6} \mathrm{H}_{4}\right) ; 3.55\left(2 \mathrm{H}, \mathrm{s}, \mathrm{C}_{1}-\mathrm{H}\right) ; 3.75(3 \mathrm{H}, \mathrm{s},-$ $\mathrm{OMe}) ; 3.78(3 \mathrm{H}, \mathrm{s}-\mathrm{OMe}) ; 6.45\left(1 \mathrm{H}, \mathrm{s}, \mathrm{C}_{8}-\mathrm{H}\right) ; 6.5(1 \mathrm{H}, \mathrm{s}$, $\left.\mathrm{C}_{5}-\mathrm{H}\right) ; 6.81\left(2 \mathrm{H}, \mathrm{d}, \mathrm{C}_{3}-\mathrm{H}, \mathrm{C}_{5}-\mathrm{H}, \mathrm{J}=8.5 \mathrm{~Hz}\right) ; 7.24(2 \mathrm{H}, \mathrm{d}$, $\left.\mathrm{C}_{2}-\mathrm{H}, \mathrm{C}_{6}-\mathrm{H}, \mathrm{J}=8.5 \mathrm{~Hz}\right) \mathrm{ppm}$.

MS m/e: $299\left(\mathrm{M}^{+}\right), 298,192,191,178,163,150,135$, 122, 121 (base) 107, etc.

(Found C: 79.4; $\mathrm{H}: 4.99 ; \mathrm{N}: 3.52 ; \mathrm{C}_{18} \mathrm{H}_{21} \mathrm{NO}_{3}$ requires $\mathrm{C}$ : 79.46; H: 5.01; N: $3.5 \%)$

The hydrochloride had the colourless needles melting at $224-226^{\circ} \mathrm{C}$ (Kametani and Okhubo, 1965). The IR and NMR spectra of the synthetic product (37) were identical with that of the authentic specimen. The melting point was not depressed upon admixture with the authentic sample.

\section{ACKNOWLEDGEMENT}

Author is extremely thankful to Professor K.P.

Tiwari, Department of Chemistry, University of Allahabad, for his valuable guidance. 


\section{REFERENCES}

Budzikiewics H., Djerassi C. and Williams D.H., 1964. Structure elucidation of natural products by Mass Spectrometry, 1, p. 174, Holden-day, Inc.

Kametani T. and Okhubo K., 1965. The structure of Sendaverine and its total synthesis, Tetrahedron Letters No 48, Page 4317-4326.

Kametani T., Okhubo K. and Naguchi I., 1966. Studies on the synthesis of heterocyclic compounds, Part CXXXV, The structure of carpaverine. J. Chem. Soc. (C), pp.715.
Kametani T. and Okhubo K., 1967. Structure of Sendaverine and its total synthesis. Chem. Pharm. Bull., 15(5): 608-612.

Kametani T., Ohkubo K. and Takano S., 1967. Studies on the synthesis of Heterocyclic compounds. J. Pharm. Soc. Japan, 87: 563.

Manske R.H.F., 1952. The alkaloids of Fumariaceous Plants. Canad. J. Am. Chem. Soc., 74(11): 28642865.

Otoman H., 1982. A novel synthesis of the 2benzylisoquinoline alkaloids, Sendaverine and corgoine aziridinium salt as reactive intermediates. J. Chem. Soc., Perkin Transactions, 1. 